\title{
Pivotal role of leptin in insulin effects
}

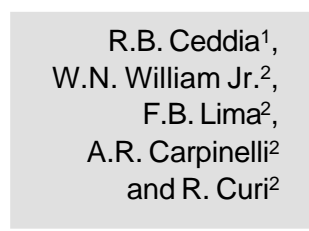

\author{
'Departamento de Educação Física, Centro de Estudos Gerais, \\ Universidade Federal Fluminense, Niterói, RJ, Brasil \\ 2Departamento de Fisiologia e Biofísica, Instituto de Ciências Biomédicas, \\ Universidade de São Paulo, São Paulo, SP, Brasil
}

\section{Correspondence \\ R. Curi \\ Departamento de Fisiologia e \\ Biofísica, ICB-1, USP \\ Av. Prof. Lineu Prestes, 1524 \\ 05508-900 São Paulo, SP \\ Brasil \\ Fax: 55 (011) 818-7285 \\ E-mail: ruicuri@bmb.icb1.usp.br \\ Publication supported by FAPESP. \\ $\ldots \ldots \ldots \ldots \ldots \ldots \ldots$}

Received August 12, 1997

Accepted January 12, 1998

\section{Abstract}

The OB protein, also known as leptin, is secreted by adipose tissue, circulates in the blood, probably bound to a family of binding proteins, and acts on central neural networks regulating ingestive behavior and energy balance. The two forms of leptin receptors (long and short forms) have been identified in various peripheral tissues, a fact that makes them possible target sites for a direct action of leptin. It has been shown that the OB protein interferes with insulin secretion from pancreatic islets, reduces insulin-stimulated glucose transport in adipocytes, and increases glucose transport, glycogen synthesis and fatty acid oxidation in skeletal muscle. Under normoglycemic and normoinsulinemic conditions, leptin seems to shift the flux of metabolites from adipose tissue to skeletal muscle. This may function as a peripheral mechanism that helps control body weight and prevents obesity. Data that substantiate this hypothesis are presented in this review.

\section{Key words}

- Leptin

- Insulin secretion

- Muscle metabolism

- Insulin resistance

- Adipocytes

\section{General properties of OB protein}

A new protein with an apparently high fat reduction effect has been recently purified (1-3). The product of the recently cloned obese $(o b)$ gene (4) provokes marked reductions in body weight, percent body fat and food intake followed by an increase in energy expenditure and a reduction in serum concentrations of glucose and insulin in obese mice (1-3). Due to its weight-reducing effect, the OB protein was called "leptin", derived from the Greek root leptós, meaning thin (2).

Leptin is a $16-\mathrm{kDa}, 146$-amino acid protein with one disulfide bond located between cysteine residues 96 and 146 originating from the $o b$ gene encoding a 4.5-kilobase adipose tissue mRNA with a highly conserved 167amino acid open reading frame. The pre- dicted amino acid sequence is $84 \%$ identical between humans and mice and has the features of a secreted protein (4). The nucleotide sequence of the $\mathrm{OB}$ protein predicted a signal sequence and this has been confirmed (5). The signal sequence is cleaved off and the mature $\mathrm{OB}$ protein is secreted into the blood. OB protein appears to circulate as a monomeric 16000-dalton protein (4). However, a family of circulating binding proteins for $\mathrm{OB}$ protein has been recently described in lean and obese humans $(6,7)$. OB protein has a C-terminal disulfide bond that appears to be critical for its activity (5). In addition, OB protein is homologous to the class I cytokine family (8). Finally, the $o b$ gene is expressed only in adipose tissues, mainly in white, but also in brown adipose tissue $(9,10)$ in proportion to adipocyte size and number (5). 


\section{The leptin receptor}

The leptin receptor $(\mathrm{Ob}-\mathrm{R})$ was first cloned from a mouse choroid plexus cDNA expression library (11) following identification of $\left[{ }^{125} \mathrm{I}\right]$-leptin binding sites in this tissue. The receptor presents considerable homology with the gp130 subunit of the interleukin-6 (IL-6) receptor and has been considered to be a member of the extended class I cytokine-receptor family (11), including IL-6, the granulocyte-colony stimulating factor and the leukemia-inhibitory factor (11, 12). However, the leptin receptor oligomerizes with itself but not with its closely related cytokine signal transducer gp130 (13).

There are at least six splice variants (a-f) of the Ob-R (14). The Ob-Ra variant, possessing a truncated intracellular domain, was the form originally cloned and it has been postulated that it serves to transport leptin across the blood-brain barrier (15). Two other splice variants, Ob-Rc and Ob-Rd, have been implicated in the clearance of leptin from the circulation and the $\mathrm{Ob}-\mathrm{Re}$ variant, having no intracellular domain, has been considered to be a putative soluble receptor that is a transport protein at the periphery $(16,17)$. The Ob-Rf is mainly expressed in tissues involved in immune regulation such as spleen and thymus, but its function remains to be elucidated (16). These variants contrast with the $\mathrm{Ob}-\mathrm{Rb}$ form which encodes a receptor with a long intracellular domain which is essential for intracellular signal transduction (11). However, a short form of the Ob-R (Ob-Ra) has been recently demonstrated to be capable of performing signal transduction (expression of immediate early genes, $c$-fos, $c$-jun and jun-B) in CHO cells supplemented with leptin (17).

Analysis of the expression pattern of the two forms (long and short) of leptin receptors by Northern blot, in situ hybridization and quantitative PCR showed that the receptors are expressed in most tissues (brain, testes, ovary, kidney, spleen, intestines, brown and white adipose tissues, heart, lung, liver, skeletal muscle, and adrenals $(14,18)$ ), with the long form being prevalent in the hypothalamus (18), in addition to also being found in the medulla of the adrenal, the inner zone of the medulla of the kidney $(16,18)$, pancreatic islets (19), and fat tissue (18).

\section{Leptin and the endocrine pancreas}

Both $o b / o b$ and $d b / d b$ mice have mutations that result in profound obesity and type II diabetes resembling that observed in a significant proportion of humans (4). Since hyperinsulinemia is a primary defect in $o b /$ $o b$ and $d b / d b$ mice and that the injection of leptin normalizes glycemia and insulinemia in $o b / o b$ mice, Kieffer et al. (20) postulated that leptin may also regulate insulin release as part of a "adipoinsular" feedback loop. They demonstrated the expression of leptin receptor mRNA in primary rat pancreatic islets and in the insulinoma cell line BTC-3. However, no information was provided on the effect of leptin upon insulin secretion.

Leclercq-Meyer et al. (21) tested the hypothesis that leptin may exert a direct inhibitory effect on insulin release from pancreatic beta cells. They investigated which isoform of the leptin receptor is expressed in rat pancreatic islets and whether leptin affects insulin release in the isolated perfused rat pancreas. At a glucose concentration of $8.3 \mathrm{mM}$, physiological leptin concentrations $(1 \mathrm{nM})$ did not alter the insulin secretion profile of the perifused pancreas. In addition, only the short form of the leptin receptor was detected in rat pancreatic islets (21). At the time the study was carried out there were no indications that the short form receptor was capable of performing signal transduction. The authors of the study (21) refuted the inhibitory effect of leptin on insulin secretion which had been postulated.

It has been shown that a functional fulllength leptin receptor $(\mathrm{Ob}-\mathrm{Rb})$ is present in $o b / o b$ mice islets (19), and recombinant leptin 
(1-100 $\mathrm{nM})$ inhibits insulin secretion in a dose-dependent manner in islets isolated from these animals. However, the same effect was not detected in animals lacking the leptin receptor ( $f a / f a$ rats and $d b / d b$ mice). Islets were kept at $16.7 \mathrm{mM}$ glucose concentration for all leptin groups. At $100 \mathrm{nM}$ leptin concentration the islets' insulin secretion response decreased to near $20 \%$ of the control group. At physiological leptin concentrations $(1 \mathrm{nM})$ there was an apparent but nonsignificant reduction in insulin secretion (19). Supraphysiological leptin concentrations were necessary to elicit a significant reduction in insulin secretion from the islets. This might be the reason why studies carried out at physiological leptin concentrations (21) have not demonstrated an effect of leptin on insulin secretion.

To test the hypothesis that leptin may interfere with insulin secretion, we investigated the acute effect of supraphysiological leptin $(50 \mathrm{nM})$ on insulin secretion and on the fractional outflow rates of ${ }^{45} \mathrm{Ca}^{2+}$ and ${ }^{86} \mathrm{Rb}^{+}$from pancreatic islets isolated from male lean albino rats (Ceddia RB, William Jr WN, Carpinelli AR and Curi R, unpublished results). At a constant physiological glucose concentration $(5.6 \mathrm{mM})$, the addition of leptin to the perifusion medium led to an increase of ${ }^{45} \mathrm{Ca}^{2+}$ fractional outflow rate followed by a significant increase $(26 \%)$ in insulin release from the islets. At low glucose concentrations $(2.8 \mathrm{mM})$, leptin also elicited a significant (50-60\%) increase in insulin secretion. At low glucose levels, islets perifused in the presence of leptin presented a lower ${ }^{86} \mathrm{Rb}^{+}$fractional outflow rate compared to perifused controls. At supraphysiological $(16.7 \mathrm{mM})$ glucose concentrations, we found that the rapid first phase insulin secretion response was blunted in the presence of leptin, but with continuation of perifusion it reached values close to those of the control group. These results led us to think of leptin as a molecule capable of modulating the insulin secretion process in beta cells, in- stead of just inhibiting or stimulating it (Ceddia RB, William Jr WN, Carpinelli AR and Curi R, unpublished results).

The initiating process of insulin secretion is the closure of ATP-sensitive $\mathrm{K}^{+}\left(\mathrm{K}^{+}-\right.$ ATP) channels, which alters the electrical activity of the cell, causing an increase in cytoplasmic $\mathrm{Ca}^{2+}$ concentration $(22,23)$.

The alteration of the ${ }^{86} \mathrm{Rb}^{+}$efflux caused by leptin (Ceddia RB, William Jr WN, Carpinelli AR and Curi R, unpublished results) suggests that its modulating effect might be associated with an alteration in the kinetics of $\mathrm{K}^{+}$-ATP channel activity (gating) present in pancreatic beta cells. Indeed, it was recently demonstrated that in cell-attached patch measurements of $o b / o b$ mouse betacells, leptin $(6.25 \mathrm{nM})$ activated ATP-sensitive potassium channels by increasing the open channel probability, while exerting no effect on mean open time (24).

Besides its effects on $\mathrm{K}^{+}$-ATP channels, leptin has also been involved in metabolic alterations within the islets. Such metabolic alterations interfere with the islets' capability to secrete insulin in response to glucose and other fuels. Recently, Zhou et al. (25) presented evidence that in pancreatic islets, leptin alters the mRNA of the genes encoding the enzymes of free fatty acid (FFA) metabolism and uncoupling protein-2 (UCP2) (25). Each normal islet contains approximately $24 \mathrm{ng}$ of triglycerides (TG), and when it is depleted of fat by hyperleptinemia, the insulin response to glucose and other fuels is completely abolished, but is promptly restored by FFA (25). The size of the TG reservoir appears to be under the control of leptin. Islets of obese, leptin-resistant ZDF rats contain $990 \mathrm{ng}$ TG per islet (26), while in rats with hyperleptinemia islet TG is zero (27).

It is also important to note that in islets of rats made hyperleptinemic by gene transfer, in which a recombinant adenovirus containing the rat leptin cDNA under the control of the cytomegalovirus (CMV) promoter 
(AdCMV-leptin) was administered, the mRNA of acetyl-CoA carboxylase was drastically reduced to $21 \%$ of the control group (free-feeding AdCMV-ß-gal infused) (25). This enzyme inhibits carnithine palmitoyltransferase (CPT-1) activity by generating malonyl-CoA (28).

In contrast, the mRNA of enzymes of FFA oxidation was significantly increased; acyl-CoA oxidase (ACO) mRNA was more than three times as high in islets of hyperleptinemic rats as in controls, and CPT-1 mRNA was almost 3 times as high. Furthermore, glycerol-3-phosphate acyltransferase mRNA, an enzyme of FFA esterification, was reduced in the islets of hyperleptinemic rats to $16 \%$ of free-feeding AdCMV-ß-gal controls (25).

Until recently, the thermogenic effects of leptin were thought to be confined to brown adipose tissue, the major site of UCP-1 expression. However, the recent discovery of UCP-2 (29), a far more ubiquitously expressed protein, raised the possibility that hyperleptinemia might up-regulate UCP-2 in tissues that express the leptin receptor $\mathrm{Ob}-$ R. UCP-2 mRNA was identified in islets of normal and hyperleptinemic rats and was expressed in the latter at over 10 times the level of pair-fed controls. Thus, up-regulation of UCP-2, like the up-regulation of ACO and CPT-1, was independent of the anorexic effect of leptin (25). Zhou et al. (25) suggested that, at least in their non-physiological model of leptin overexpression, the effects of leptin observed in vivo may largely represent direct actions not mediated via the hypothalamus.

\section{Leptin and the insulin-sensitive tissues}

It is also important to identify the possible metabolic effects of leptin on insulinsensitive tissues, since they indirectly interfere with the pancreatic insulin secretion profile. Skeletal muscle and adipose tissue are the most important sites of postprandial glucose disposal, and in these tissues the stimulation of glucose uptake, glycogen synthesis and lipid synthesis are the main effects of insulin. The leptin receptor has been identified in muscle and in adipose tissue $(14,18)$, a fact that makes these tissues possible target sites for the action of leptin.

\section{Skeletal muscle}

The molecular mechanism causing skeletal muscle insulin resistance in obese people is still poorly understood. It has been speculated that circulating factors derived from adipose tissue impair insulin signaling in the skeletal muscle cell. In addition, it was recently demonstrated that a short form of the Ob- $\mathrm{R}$ is expressed in this tissue $(14,18)$. Previous studies have reported that daily intraperitoneal injections of leptin for 28 days produce a significant dose-dependent reduction in glycemia and insulinemia in $o b /$ $o b$ mice but not in lean mice (1), and also caused a reduction in body weight when injected intracerebroventricularly into rats fasted for $24 \mathrm{~h} \mathrm{(30).}$

Pair-feeding studies (31) have pointed out that food intake does not completely account for reduction of adipose tissue after OB protein infusion, suggesting a significant metabolic regulatory role for leptin. Although suggesting that leptin has a clear effect on glucose metabolism, very few data have been published regarding this issue. A few studies have reported that leptin impairs the intracellular insulin receptor signaling pathway in rat- 1 fibroblasts, NIH3T3 cells (32) and HepG2 cells (33), suggesting that leptin may antagonize some effects of insulin.

In contrast, our findings (Ceddia RB, William Jr WN and Curi R, unpublished results) provide evidence that in skeletal muscle of lean rats, leptin exerts an insulinlike effect, which is in accordance to the results observed with $\mathrm{C}_{2} \mathrm{C}_{12}$ myotubes (34).

Insulin $(100(\mu \mathrm{U} / \mathrm{ml})$ increased 2-deoxyglucose (2-DG) uptake by two-fold while the 
leptin group (100 nmol/l) reached $75 \%$ of the insulin response after 1-h incubation. Leptin elicited a significant increase $(27.7 \%)$ in total lactate production, accompanied by a 3-fold increment in glycogen synthesis from $\left[\mathrm{U}-{ }^{14} \mathrm{C}\right] \mathrm{D}$-glucose. Insulin raised glycogen synthesis by 6 -fold. The leptin plus insulin group increased glycogen synthesis by 8 fold, which is equivalent to the sum of the separate leptin and insulin groups. It is reasonable to assume that leptin per se exerts an insulin-like effect stimulating glucose uptake, glycogen synthesis, and lactate formation and also seems to potentiate the effect of insulin on glucose incorporation into glycogen in incubated soleus muscle (Ceddia RB, William Jr WN and Curi R, unpublished results).

The mechanism by which leptin exerts such insulin-like effect remains to be determined. However, as previously postulated, there seems to be a crosstalk between the leptin and insulin intracellular signaling pathways at the level of phosphatidylinositol-3 kinase (PI3-kinase) (34). In skeletal muscle, the effect of insulin on glucose uptake is mainly mediated by GLUT4 translocation. A central role of PI3-kinase both in the signaling to GLUT4 translocation and in glycogen synthesis has been demonstrated $(35,36)$.

\section{Adipocytes}

Adipocytes are far from being just fuel storage compartments. These cells are responsible for secreting molecules (i.e., leptin, adipsin) that may act as hormones signaling to various tissues in both animals and humans $(4,37)$.

Since the identification of the OB protein receptor in adipocytes $(14,18)$, it has been speculated that leptin might also exert an autocrine effect. However, very few data are available regarding this issue. Recently, it was demonstrated that in isolated rat adipocytes, leptin impairs the metabolic actions of insulin (38).
At low leptin levels $(<1 \mathrm{nM})$, the insulin sensitivity of adipocytes was significantly reduced, but the maximum rate of glucose uptake was not altered. In the presence of 2 $\mathrm{nM}$ leptin, both the sensitivity to insulin and the maximum rate of 2-DG uptake were significantly reduced. At higher leptin concentrations the responsiveness to insulin was progressively diminished, resulting in nearly complete inhibition of insulin effects at $>30$ $\mathrm{nM}$ leptin. It was also reported that leptin inhibits glycogen synthase activity, protein synthesis and lipogenesis while increasing lipolysis and protein kinase A activation (38). In contrast to these dramatic inhibitory actions of leptin on insulin-stimulated effects, leptin did not reduce glucose uptake or lipogenesis in the absence of insulin, but slightly increased them (1.3-fold at $100 \mathrm{nM})$. According to Müller et al. (38), at least in freshly isolated rat adipocytes, leptin impairs a broad spectrum of insulin actions in a specific manner.

Results obtained in our laboratory (Ceddia RB, William Jr WN, Lima FB and Curi R, unpublished results) also indicate that, in the absence of insulin, leptin stimulates 2-DG uptake in rat isolated adipocytes (Figure 1). In the presence of leptin $(1 \mathrm{ng} / \mathrm{ml})$, there was a significant $(\sim 80 \%)$ increase in 2-DG uptake. Higher leptin values did not seem to cause any further increase in glucose transport. The mechanisms responsible for these opposite effects of leptin on adipocytes and other cell types remain to be clarified. However, the pleiotropic character of the effects of leptin suggests early interference with the insulin signaling cascade, close to the insu-

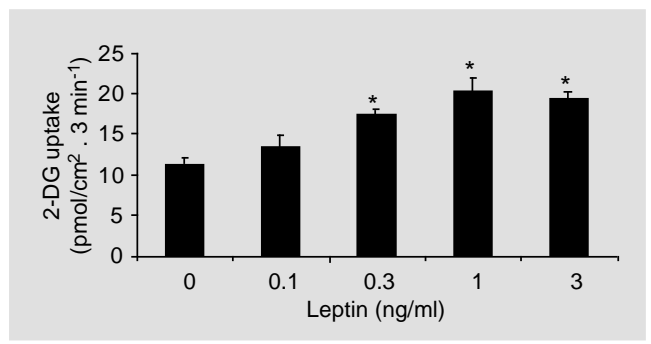

Figure 1 - 2-Deoxy-glucose (2DG) uptake $\left(\mathrm{pmol} / \mathrm{cm}^{2} .3 \mathrm{~min}^{-1}\right)$ in isolated adipocytes in the presence of leptin. Each point represents the mean value \pm SEM of three different incubation experiments with five samples in each leptin group. Adipocytes were extracted from male albino rats (Wistar strain), cultivated for $15 \mathrm{~h}$ in the presence and absence of leptin and subsequently assayed for 2-DG transport. ${ }^{*} \mathrm{P}<0.05$ compared to basal levels (no leptin) (ANOVA). 
lin receptor (38). This seems to be compatible with the preliminary findings that leptin inhibits insulin receptor kinase activity and phosphorylation of IRS-1 following insulin stimulation in rat-1 fibroblasts overexpressing the human insulin receptor (32). Also, that the exposure of human hepatic cells to leptin, at concentrations comparable to those present in obesity, causes attenuation of several insulin-induced activities, including tyrosine phosphorylation of IRS-1, association of the adapter molecule growth factor receptor bound protein 2 with IRS-1, and down-regulation of gluconeogenesis. In contrast, leptin increases the activity of IRS-1associated PI3-kinase, suggesting that leptin modulates insulin activities through the existence of a "crosstalk" between the signaling pathways downstream from insulin and leptin receptors $(33,39)$.

\section{Pivotal role of leptin in insulin effects}

According to the present findings, it is reasonable to assume that leptin plays a pivotal role in the effect of insulin. Leptin produced by the adipose tissue exerts an autocrine inhibitory effect on insulin-stimulated glucose uptake and increases lipolysis. Skeletal muscle increases glucose uptake, glycogen synthesis, and fatty acid oxidation in the presence of leptin. Insulin secretion seems to be modulated by leptin. On the other hand, insulin stimulates leptin production in adipocytes, indicating the existence of an "adipoinsular axis" (Figure 2).

\section{Flux shifting hypothesis of leptin}

Leptin seems to be involved in a myriad of metabolic processes with different effects in various tissues. The previously discussed topics, considered as a whole, led us to conclude that leptin is a hormone that plays its metabolic roles either indirectly (signaling to centers located in the central nervous system) or by acting directly on its target cells.

The endocrine pancreas, skeletal muscle and adipose tissue are three well-related sites where leptin seems to act directly, orchestrating a complex integrative "adipoinsular" axis (20). It has been shown that leptin secretion is directly proportional to size and number of adipocytes (8), and that the expression of $o b$ mRNA is stimulated by insulin $(40,41)$. Starvation suppresses $o b$ mRNA expression and refeeding reverses it (42).

Here, we raise the hypothesis that, under physiological conditions (normo-glycemia and normo-insulinemia), leptin shifts the flux of metabolites from adipocytes to skeletal
Figure 2 - Summary of the pivotal role of leptin in insulin secretion and insulin responsiveness in skeletal muscle and adipocytes. $\oplus$ stimulates, $\uparrow$ increase, $\downarrow$ decrease. TG, Triglycerides.

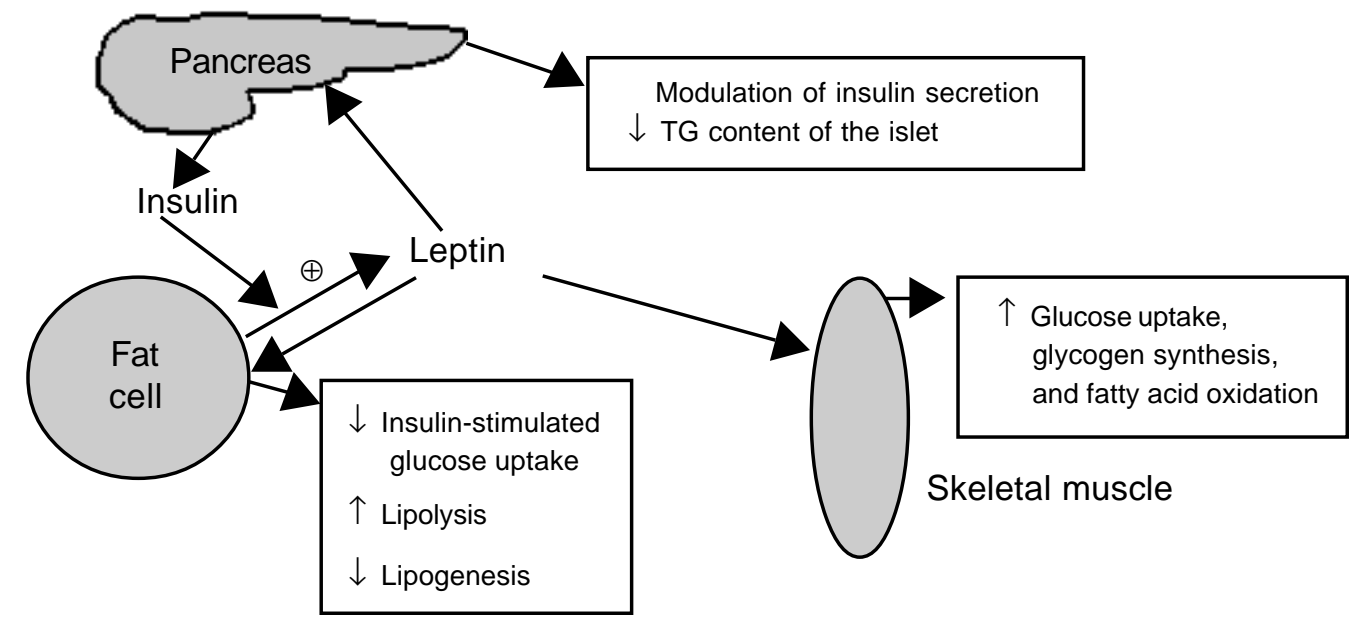




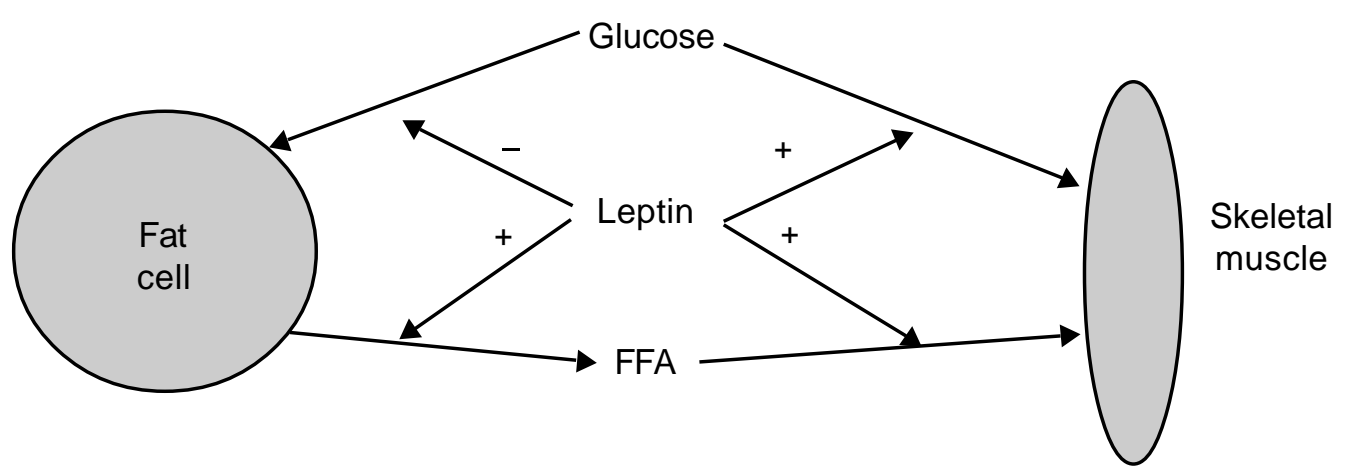

Figure 3 - Metabolic flux shifting hypothesis for leptin. + Stimulates, - inhibits. FFA = free fatty acids.

muscle (Figure 3). Insulin-stimulated glucose uptake and lipogenesis are reduced while lipolysis is increased by leptin in adipose tissue. Skeletal muscle increases glucose uptake and glycogen synthesis in the presence of leptin (Figure 1). This may function as a peripheral mechanism that controls body weight. A loss of sensitivity to leptin (leptin resistance) may permit an imbalanced storage of energy culminating in obe- sity. Our hypothesis is compatible with findings from human studies showing that, differently from $o b / o b$ mice, obesity is not a problem of lack of leptin, since high levels of this hormone have been found in obese subjects $(43,44)$. Therefore, obesity might occur due to a disruption in the leptin signaling pathway to its target sites, either central or peripherally located.

\section{References}

1. Pelleymounter MA, Cullen MJ, Baker MB, Hecht R, Winters D, Boone T \& Collins F (1995). Effects of the obese gene product on body weight regulation in $o b / o b$ mice. Science, 269: 540-543.

2. Halaas JL, Gajiwala KS, Maffei M, Cohen SL, Chait BT, Rabinowitz D, Lallone RL, Burley SK \& Friedman JM (1995). Weightreducing effects of the $o b$ plasma protein encoded by the obese gene. Science, 269: 543-546.

3. Campfield LA, Smith FJ, Guisez Y, Devos R \& Burn P (1995). Recombinant mouse ob protein: Evidence for a peripheral signal linking adiposity and central neural networks. Science, 269: 546-549.

4. Zhang $\mathrm{Y}$, Proença R, Maffei M, Barone M, Leopold L \& Friedman JM (1994). Positional cloning of the mouse obese gene and its human homologue. Nature, 372: 425-432.

5. Campfield LA, Smith FJ \& Burn P (1996). The OB protein (leptin) - A link between adipose tissue mass and central neural networks. Hormone and Metabolic Research, 28: 619-632.

6. Sinha M, Opentanova I, Ohannesian JP, Kolackzinski JW, Heiman M, Hale J, Becker G, Bowsher R, Stephens T \& Caro
JF (1996). Evidence of free and bound leptin in human circulation: studies in lean and obese subjects and during short-term fasting. Journal of Clinical Investigation, 98: 1277-1282.

7. Diamond FB, Eichler DC, Duckett G, Jorgensen EV, Shulman D \& Root AW (1997). Demonstration of a leptin binding factor in human serum. Biochemical and Biophysical Research Communications, 233: 818-822.

8. Madej T, Boguski MS \& Bryant SH (1995). Threading analysis suggests that the obese gene product may be a helical cytokine. FEBS Letters, 373: 13-18.

9. Moinat $M$, Deng $C$, Muzzin $P$, Assimacopoulos-Jeannet F, Seydoux J, Dulloo AG \& Giacobino J-P (1995). Modulation of obese gene expression in rat brown and white adipose tissue. FEBS Letters, 373: 131-134.

10. Remesar X, Rafecas I, Fernández-López JÁ \& Alemany M (1997). Leptin. Medicinal Research Reviews, 17: 225-234.

11. Tartaglia LA, Dembski M, Weng X, Deng N, Culpepper J, Devos R, Richards GJ, Campfield LA, Clark FT, Deeds J, Muir C, Sanker S, Moriarty A, Moore KJ, Smutko JS, Mays GG, Woolf EA, Moroe CA \&
Tepper RI (1995). Identification and expression cloning of a leptin receptor, OBR. Cell, 83: 1263-1271.

12. Pelleymounter M (1997). Leptin and the physiology of obesity. Current Pharmaceutical Design, 3: 85-98.

13. Nakashima K, Narazaki M \& Taga T (1997) Leptin receptor (OB-R) oligomerizes with itself but not with its closely related cytokine signal transducer gp130. FEBS Letters, 403: 79-82.

14. Hoggard N, Mercer JG, Rayner DV, Moar K, Trayhurn P \& Williams LM (1997). Localization of leptin receptor mRNA splice variants in murine peripheral tissues by RT-PCR and in situ hybridization. Biochemical and Biophysical Research Communications, 232: 383-387.

15. Lee GH, Proença R, Montez JM, Carrol KM, Darvishzadeh JG, Lee JI \& Friedman JM (1996). Abnormal splicing of the leptin receptor in diabetic mice. Nature, 379: 632-635.

16. Wang $M-Y$, Zhou $Y T$, Newgard $C B$ \& Unger RH (1996). A novel leptin receptor isoform in rat. FEBS Letters, 392: 87-90.

17. Murakami T, Yamashita T, lida M, Kuwajima M \& Shima K (1997). A short form of leptin receptor performs signal transduc- 
tion. Biochemical and Biophysical Research Communications, 231: 26-29.

18. Luoh S-M, Di Marco F, Levin N, Armanini M, Xie M-H, Nelson C, Bennett GL, Williams $M$, Spencer AS, Gurney A \& de Sauvage FJ (1997). Cloning and characterization of a human leptin receptor using a biologically active leptin immunoadhesin. Journal of Molecular Endocrinology, 18: 77-85.

19. Emilsson V, Liu Y-I, Cawthorne MA, Morton NM \& Davenport M (1997). Expression of the functional leptin receptor mRNA in pancreatic islets and direct inhibitory action on insulin secretion. Diabetes, 46: 313-316.

20. Kieffer TJ, Heller RS \& Habener JF (1996). Leptin receptors expressed on pancreatic B-cells. Biochemical and Biophysical Research Communications, 224: 522-527.

21. Leclercq-Meyer V, Considine RV, Sener A \& Malaisse WJ (1996). Do leptin receptors play a functional role in the endocrine pancreas? Biochemical and Biophysical Research Communications, 229: 794-798.

22. Carpinelli AR \& Malaisse WJ (1980). Regulation of ${ }^{86} \mathrm{Rb}^{+}$outflow from pancreatic islets. III. Possible significance of ATP. Journal of Endocrinology, 4: 363-370.

23. Dukes ID \& Philipson LH (1996). $\mathrm{K}^{+}$channels: Generating excitement in pancreatic B-cells. Diabetes, 45: 845-853.

24. Kieffer TJ, Heller RS, Leech CA, Holz GG \& Habener JF (1997). Leptin suppression of insulin secretion by the activation of ATP-sensitive $\mathrm{K}^{+}$channels in pancreatic B-cells. Diabetes, 46: 1087-1093.

25. Zhou YT, Shimabukuro M, Koyama K, Lee Y, Wang MY, Trieu F, Newgard CB \& Unger RH (1997). Induction by leptin of uncoupling protein-2 and enzymes of fatty acid oxidation. Proceedings of the $\mathrm{Na}$ tional Academy of Sciences, USA, 94: 6386-6390.

26. Lee $W$, Hirose $H$, Ohneda $M$, Johnson JH, McGarry JD \& Unger RH (1994). BCell lipotoxicity in the pathogenesis of non-insulin dependent diabetes mellitus of obese rats: Impairment in adipocyte- $B$ cell relationships. Proceedings of the $\mathrm{Na}$ tional Academy of Sciences, USA, 91: 10878-10882.
27. Shimabukuro M, Koyama K, Chen G, Wang M-Y, Trieu F, Lee Y, Newgard CB \& Unger RH (1997). Direct antidiabetic effect of leptin through triglyceride depletion of tissues. Proceedings of the National Academy of Sciences, USA, 94: 4637-4641.

28. McGarry JD \& Foster DW (1980). Regulation of hepatic fatty acid oxidation and ketone body production. Annual Review of Biochemistry, 49: 395-420.

29. Fleury C, Neverona M, Collins S, Raimbault S, Champinhy O, LeviMeyrueis C, Bouillard F, Seldin M, Surwit RS, Ricquier D \& Warden C (1997). Uncoupling protein-2: a novel gene linked to obesity and hyperinsulinemia. Nature Genetics, 13: 18-19.

30. Al-Baranji KA, Buckingham RE, Haynes AC, McBay DL, Mossakowska DE, Tadayyon M, Wang SM \& Arch JRS (1996). Effects of a single central leptin injection on food intake and body weight in rats. International Journal of Obesity, 20 (Suppl 4): 77 (Abstract).

31. Levin N, Nelson C, Gurney A, Vandlen R \& de Sauvage $F$ (1996). Decreased food intake does not completely account for adiposity reduction after $o b$ protein infusion. Proceedings of the National Academy of Sciences, USA, 93: 1726-1730.

32. Kroder G, Kellerer M \& Haring HU (1996). Effect of leptin on insulin signaling in rat-1 fibroblasts overexpressing HIR. Experimental and Clinical Endocrinology, 104 (Suppl 2): 66 (Abstract).

33. Cohen B, Novick D \& Rubinstein M (1996). Modulation of insulin activities by leptin. Science, 274: 1185-1188.

34. Berti L, Kellerer M, Capp E \& Haring HU (1997). Leptin stimulates glucose transport and glycogen synthesis in $\mathrm{C}_{2} \mathrm{C}_{12}$ myotubes: evidence for a PI3-kinase mediated effect. Diabetologia, 40: 606-609.

35. Okada T, Kawano Y, Sakakibara T, Hazeki O \& Ui M (1994). Essential role of phosphatidylinositol 3-kinase in insulin-induced glucose transport and antilipolysis in rat adipocytes. Studies with a selective inhibitor wortmannin. Journal of Biological Chemistry, 269: 3568-3573.

36. Welsh GI, Foulstone EJ, Young SW,
Tavare JM \& Proud CG (1994). Wortmannin inhibits the effects of insulin and serum on the activities of glycogen synthase kinase- 3 and mitogen-activated protein kinase. Biochemical Journal, 303: 15-20.

37. Flier JS, Lowell B, Napolitano A, Usher P, Rosen B, Cook KS \& Spiegelman B (1989). Adipsin: Regulation and dysregulation in obesity and other metabolic states. Recent Progress in Hormone Research, 45: 567-581.

38. Müller G, Ertl J, Gerl M \& Preibish G (1997). Leptin impairs metabolic actions of insulin in isolated rat adipocytes. Journal of Biological Chemistry, 272: 1058510593.

39. Taylor SI, Barr V \& Reitman M (1996). Does leptin contribute to diabetes caused by obesity? Science, 274: 151-152.

40. Hardie LJ, Rayner DV, Holmes S \& Trayhurn P (1996). Circulating leptin levels are modulated by fasting, cold exposure and insulin administration in lean but not Zucker (fa/fa) rats as measured by ELISA. Biochemical and Biophysical Research Communications, 223: 660-665.

41. Kolaczynski JW, Nyce MR, Considine RV, Boden G, Nolan JJ, Henry R, Mudaliar SR, Olefsky J \& Caro JF (1996). Acute and chronic effect of insulin on leptin production in humans. Studies in vivo and in vitro. Diabetes, 45: 699-701.

42. Frederich RC, Löllmann $B$, Hamann $A$ Napolitano-Rosen A, Khan BB, Lowell BB \& Flier JS (1995). Expression of ob mRNA and its encoded protein in rodents. Journal of Clinical Investigation, 96: 16581663

43. Considine RV, Sinha MK, Heiman ML, Kriauciunas A, Stephens TW, Nyce MR, Ohannesian JP, Marco CC, McKee LJ, Baur TL \& Caro JF (1996). Serum immunoreactive-leptin concentrations in normal-weight and obese humans. New England Journal of Medicine, 334: 292-295.

44. Wing RR, Sinha MK, Considine RV, Lang W \& Caro JF (1996). Relationship between weight loss maintenance and changes in serum leptin levels. Hormone and Metabolic Research, 28: 698-703. 